\title{
CRITICAL SUCCESS FACTORS OF JAVA PREANGER COFFEE CHAIN IN BANDUNG REGENCY
}

\author{
Muhammad Taufik Perdana ${ }^{1 *}$, Ratya Anindita ${ }^{2}$, Suhartini ${ }^{2}$ \\ ${ }^{1}$ Magister of Agriculture economies, Brawijaya University, Indonesia \\ ${ }^{2}$ Lecturer of agricultural Socio Economics/ Agribussiness Department, University of Brawijaya, Indonesia \\ *corresponding author: Perdana.taufik@gmail.com
}

\begin{abstract}
The Purpose of this research is to identify and analyse the critical success factor of Java Preanger Coffee in achieving competitive advantage. The method of these research is using qualitative method using critical success factor analysis. Data analysis technique using descriptive analysis qualitative that compared obtained data with the theories. An Strategy to improve competitive advantage of coffee Java preanger will be the main objective of these researchThe factors that become the critical factor is aroma, serving methods, Price, Packaging, stock, roasting quality, innovation, roasting date, Serving quality, Barista role. Strategy to improve the product and make a market penetration to increase market competitiveness. Based on the result of analysis can be concluded that aroma and roasting quality have a high point of critical sucess with score of 6.58 and 6.55 from maximum 7 points. Packaging having the lowest score with 5.82 points. These results show us that the important role from coffee industry was the production, post harvest and processing factor that create an unique aroma and flavour for the competitive advantage and increase the benefit and value.The Purpose of this research is to identify and analyse the critical success factors of Java Preanger Coffee in achieving Competitive advantage. The method of these research is using critical success factor analysis. The observation and data collected are used to describe factors affecting Java Preanger Coffee. The results found that the factors used for improvemen in competitive advantage of coffee Java preanger are aroma, serving methods, price, packaging, stock, roasting quality, innovation, roasting date, serving quality, and barista role. Based on the results can be concluded that aroma and roasting quality have a high point of critical sucess with score of 6.58 and 6.55 from maximum 7 points. Packaging has the lowest score with 5.82 points. Additionally, the important role of coffee industry was the production, post harvest and processing that create an unique aroma and flavour for the competitive advantage and increase the benefit and value.
\end{abstract}

Keywords: Critical success factor, java preanger coffee, aroma, roasting quality

\section{INTRODUCTION}

Indonesian export in coffee commodities increase $9,2 \%$ / year , $40 \%$ was arabica coffee or likely known as single origin coffee or geographical coffee (Ditjenbun, 2014). Arabica Coffee is premium grade coffee that processed by post harvesting technology with detail monitoring to make special flavour and fragrance.

Price and demand of single origin coffee increasing rapidly compare with other coffee. Consumption pattern in world change from just consuming become coffee apreciate, thisi pattern called as third wave coffee. Research by National
Coffee Association showes that specialy arabica coffee consumption reach $30 \%$ coffee consumption in America (Gaille, 2013).

Indonesia has various types of arabica coffee that will be potential commodities in the domestic and international coffee industry. Arabica coffee which is widely known in the global market is Lintong Coffee, Toraja Coffee, Gayo Coffee, Bali Kintamani Coffee, Baliem Arabica Coffee and Flores Bajawa Coffee and Java Preanger Coffee from West Java.

Java Preanger was part of single origin coffee that has potential to develop especially in 
marketing aspect. This coffee has an historical background as the first Indonesian coffee that exported to Amsterdam in 1711. It is known as A Cup of Java. This background will be a benefit to compete in Global Value Chain or international market. Java Preanger arabica coffee has uniqueness in the aroma and taste.The smell is the smell of caramel and nuts. In addition, this coffee can be said to be light or smooth coffee. These attributes increase the added value and will be able to compete in the global market.

Java preanger coffee type is named after the mountain in West Java such as Manglayang Mountain, Malabar Mountain and Puntang Mountain. Java Preanger is a coffee from West Java that has been exported and has good marketing potential to enter the international market.

The research is needed to analyze the key factors or crtical factors that influence consumer preference to consume Java Preanger Coffee. These research objectives are to identify critical sucess factors in Java Preanger Coffee in Bandung Regency.

Grunert et al. (2005) defined market orientation in value chain as a condition which the actors in chain should responding need and consumer preference now and in the future.Critical Success Factor's Analysis useful for knowing which factors that important in coffee products and will become producer concern to improve their product, especially in on-farm and off-farm to fullfill the consumer preference.

\section{RESEARCH METHODS}

\section{Study Area and Data Collected}

This study was conducted in Bandung Regency, West-Java Province, Indonesia. The data were collected on April up to June 2017. The total respondents are 43 respondents consist of 40 java preanger coffee consumer and 3 java preanger coffee producer/ farmer.

\section{Critcal Success Factor Method}

Critical Success Factor (CSF) was an analysis tool to see the impact factors of success or failure in product. The objective of this analysis is to get information that useful to increase competitive advantage of the product. CSF plays important role in strategic planning because it becomes a media that connect bussiness startegy with coffee farmer, with detail and strategic planning. This will generate the useful information to make a priority of which factors that important it will make improvement for the product especially in competitiveness related to consumer preferences in arabica coffee.

Factors that become key success of the product have special elements such as information, competency in technology and innovation. These elements will affect product and company bargaining in the market. Two type factors of CSF in company are internal and external factor. Internal factors are affected by management activity like costs, quality, and service and external factors are affected by competitor behaviour, Goverment policy and technology (Krugman and Anthony, 1995)

After identifying the factors, we will continue with scoring the factors in order to understand which factors are the important factors in Java Preanger coffee industry. The scoring methods was based on scale of importance of the factors in industry, scoring from point $1=$ Not very important, $2=$ not important, $3=$ Moderately important, $4=$ Not too important, $5=$ Fairly important, $6=$ important, dan $7=$ Critically important (Kaplinsky and Morris, 2000).

Table 1. Assesment Scale of CSF

\begin{tabular}{cl}
\hline Scale & \multicolumn{1}{c}{ Assesment } \\
\hline 1 & Not very important \\
2 & Not Important \\
3 & Moderately Important \\
4 & Not too Important \\
5 & fairly Important \\
6 & Important \\
7 & Critically Important \\
\hline Source $:$ & Kaplinsky Morris 2001
\end{tabular}

\section{RESULTS AND DISCUSSION Respondent Characteristics}

The respondents characteristic regarding the age distribution shows that coffee consumer are in young people with the age less than 30 years, i.e $62.5 \%$ from total 40 respondents. There is only $27.5 \%$ in $30-40$ years old coffee consumer. In education level, the majority of coffee consumer has education in high school education or college. It is about $80 \%$ of respondents.

Java preanger or single origin coffe have a specified consumer usually at the middle and high income, based on survey $68 \%$ consumer of Java 
Preanger coffee respondents have income more than IDR 2.5 million.

Coffee producers especially coffee farmers in Bandung Regency have various pattern and methods to sell their products to the hands of end consumers. The value chain connects the producer to the market in various ways either directly or indirectly. The condition will determine the characters of value chain, including in buyer and producer characteristics. The analysis in this step tries to identify factor that affect consumer preference in coffee industry. Factors that become main observation in this analysis are aroma, price, packaging, standard, serving method, roasting quality, roasting date, barista role, service, Innovation and technology.

These factors will be analyzed by scale of importance 1 until 7 and it will comparing the importance factor between producer perspective with consumers. From the gap beetween producer and consumer, there will bean opportunity for improving ad upgrading coffee industry. Besides that it will be tested by validity and reliability test to shows how far the measuring instrument is used in measuring what is measured. Detail definition of the factors showed in Table 2.

Tabel 2. Critical Success Factor (CSF) Java Preanger Coffee Definition

\begin{tabular}{|c|c|c|c|}
\hline No & Variable & Definition & Indicator \\
\hline 1. & Aroma & $\begin{array}{l}\text { Aroma was a } \\
\text { fragrance in coffee } \\
\text { after brewing } \\
\text { process }\end{array}$ & $\begin{array}{l}\text { Have a specific } \\
\text { fragrance and not } \\
\text { having a bad smell }\end{array}$ \\
\hline 2. & $\begin{array}{l}\text { Serving } \\
\text { Method }\end{array}$ & $\begin{array}{l}\text { Method to brewing } \\
\text { coffee such as V60, } \\
\text { espresso, French } \\
\text { press, and others. }\end{array}$ & $\begin{array}{l}\text { Serving method } \\
\text { must done based } \\
\text { in procedure and } \\
\text { in the right step of } \\
\text { process. }\end{array}$ \\
\hline 3. & Price & $\begin{array}{l}\text { Product value that } \\
\text { indicate by } \\
\text { willingness to pay } \\
\text { by the consumer }\end{array}$ & $\begin{array}{l}\text { Price above } \\
\text { production cost }\end{array}$ \\
\hline 4. & Packaging & $\begin{array}{l}\text { Standard packaging } \\
\text { that attractive and } \\
\text { also safe for } \\
\text { consumption and } \\
\text { storage }\end{array}$ & $\begin{array}{l}\text { The packaging } \\
\text { size corresponds } \\
\text { to the product's } \\
\text { weight, does not } \\
\text { leak and displays } \\
\text { product-related } \\
\text { information with } \\
\text { details. }\end{array}$ \\
\hline 5. & Stock & $\begin{array}{l}\text { Coffee bean } \\
\text { availability }\end{array}$ & Stock fulfilled \\
\hline 6. & $\begin{array}{l}\text { Roasting } \\
\text { Quaity }\end{array}$ & $\begin{array}{l}\text { The condition and } \\
\text { type of roasted } \\
\text { coffee is done by a } \\
\text { roaster that has } \\
\text { certification of } \\
\text { expertise }\end{array}$ & $\begin{array}{l}\text { Pass the cupping } \\
\text { stage and have a } \\
\text { level of roasting } \\
\text { that is suitable and } \\
\text { evenly distributed }\end{array}$ \\
\hline
\end{tabular}

\begin{tabular}{|c|c|c|c|}
\hline 7. & $\begin{array}{l}\text { Innovation } \\
\& \\
\text { Technology }\end{array}$ & $\begin{array}{l}\text { Increasing quality of } \\
\text { coffe product by } \\
\text { modern technology } \\
\text { and innovation } \\
\text { especially in } \\
\text { seedling and } \\
\text { processing phase }\end{array}$ & $\begin{array}{l}\text { Developing } \\
\text { sustainable } \\
\text { innovation and } \\
\text { update the modern } \\
\text { technology in } \\
\text { coffee industry }\end{array}$ \\
\hline 8. & $\begin{array}{l}\text { Roasting } \\
\text { date }\end{array}$ & $\begin{array}{l}\text { The processing date } \\
\text { of roasting phase }\end{array}$ & $\begin{array}{l}\text { The date always } \\
\text { available }\end{array}$ \\
\hline 9. & Service & $\begin{array}{l}\text { Procedures in } \\
\text { performing services } \\
\text { and presentation to } \\
\text { consumers }\end{array}$ & $\begin{array}{l}\text { Customer } \\
\text { satisfaction }\end{array}$ \\
\hline 10. & Barista role & $\begin{array}{l}\text { A person who brings } \\
\text { coffee with various } \\
\text { types of presentation } \\
\text { methods and has } \\
\text { special expertise }\end{array}$ & $\begin{array}{l}\text { Perform brewing } \\
\text { of coffee } \\
\text { according to the } \\
\text { procedure and } \\
\text { make it interesting } \\
\text { and on time }\end{array}$ \\
\hline 11. & Standard & $\begin{array}{l}\text { Standard } \\
\text { specification } \\
\text { procedures based on } \\
\text { safety, health, } \\
\text { environmental } \\
\text { safety, science and } \\
\text { technology } \\
\text { development. }\end{array}$ & $\begin{array}{l}\text { Halal certification, } \\
\text { circulation } \\
\text { certification and } \\
\text { distribution } \\
\text { authorization }\end{array}$ \\
\hline
\end{tabular}

Source : Survey 2017

\section{Validity and Reliability Test Results}

Validity is a test done to see how well items in questionnaire measure of a variable are. Comparing the correlation index of Pearson moment productivity uses $5 \%$ significant level. Or by comparing the significance with alpha $=5 \%$, it is said to be valid if the value is $r>r$ critical or the value of significance $<0.05$, otherwise if the value $r$ count $<\mathrm{r}$ critical or significance value $>0.05$ then the item is said to be invalid. The results can be seen in Table 3.

Table 3. Validity and Reliabilities Test Score

\begin{tabular}{|c|c|c|c|c|c|}
\hline No & Variabel & $r_{\text {stat }}$ & \multicolumn{2}{|c|}{ Sig $r$} & $\begin{array}{l}\text { Alpha } \\
\text { Cronba }\end{array}$ \\
\hline 1 & Aroma & 0.504 & 0.001 & Valid & \\
\hline 2 & $\begin{array}{l}\text { Serving } \\
\text { Method }\end{array}$ & 0.446 & 0.004 & Valid & \\
\hline 3 & Price & 0.473 & 0.002 & Valid & \\
\hline 4 & Packaging & 0.517 & 0.001 & Valid & \\
\hline 5 & Stock & 0.501 & 0.001 & Valid & \\
\hline 6 & $\begin{array}{l}\text { Roasting } \\
\text { Quality }\end{array}$ & 0.425 & 0.006 & Valid & 0,665 \\
\hline 7 & $\begin{array}{l}\text { Innovation and } \\
\text { technology }\end{array}$ & 0.431 & 0.005 & Valid & \\
\hline 8 & roasting date & 0.467 & 0.002 & Valid & \\
\hline 9 & Service & 0.55 & 0.000 & Valid & \\
\hline 10 & Barista roles & 0.442 & 0.004 & Valid & \\
\hline 11 & Standardization & 0.594 & 0.000 & Valid & \\
\hline
\end{tabular}

Source: Analysis results, 2017 
Based on Table 2, it is understood that, CSF indicators such as scent, presentation method, price, packaging, stock, roasting type and quality, innovation and technology, roasting date, service, barista role, certification and standardization are all valid. One invalid component is flavor because $r$ counts smaller than $\mathrm{r}$ table. The result of Alpha Cronbach value is 0.665> 0.6. Based on the determination, it can be concluded that the critical success factor (CSF) indicator is reliable.

\section{Comparison of coffee farmer's interest rate with consumers}

The variables in this study consist of scent, presentation method, price, packaging, stock, type and quality of roasting, innovation and technology, roasting date, service, barista role, certification and standardization. This variable will be compared between coffee producers, in this case is farmers, and also the responses from consumers. So, it can be seen the gap preference between consumers and producers. Next, it will be used as one input in doing upgrading or improvement of the product. The following is the calculation of critical success factor of agroindustry and final consumer as presented in Table 4.

Table 4. Critical Success Factor value

\begin{tabular}{lrrr}
\hline \multirow{2}{*}{ CSF Variable } & \multicolumn{2}{c}{ Perception } & \multirow{2}{*}{ Gap } \\
\cline { 2 - 3 } & Farmer & Consumer & \\
\hline Smell & 6.33 & 6.58 & 0.25 \\
Serving method & 6.00 & 6.18 & 0.18 \\
Price & 6.33 & 6.03 & 0.31 \\
Packaging & 5.33 & 5.82 & 0.48 \\
Stock & 6.00 & 6.11 & 0.11 \\
Roasting quality & 7.00 & 6.55 & 0.45 \\
Innovation and & 5.33 & 6.13 & 0.8 \\
technology & & & \\
Roasting date & 6.33 & 6.18 & 0.15 \\
Service & 6.33 & 5.97 & 0.36 \\
Barista roles & 6.33 & 6.16 & 0.18 \\
Standardization & 6.33 & 6.16 & 0.18 \\
\hline Source : Anatysin Results & 2017 & &
\end{tabular}

Source : Analysis Results 2017
Based on Table 4, it explans about Critical Success Value in each variable. It can be seen that from the farmer point of view factors the important variables are type and roasting quality. It reaches the highest with a score of 7 . This is because the roasting process has an important role in determining the character of coffee and to improve the quality and price of coffee products.

In addition to these prices, services, baristas roles, certifications, roasting dates and aroma become another important factor with a high score of 6.33. Those attractive factors are important in increasing consumer interest to buy coffee products.

While the factors that have the lowest score on the producer side are packaging, innovation and technology, those are because majority farmers did not package their products themselves. Roasters and other processors package and develop more the product.

The most important factors that affect the consumer is the scent with a score of 6.58. The aroma in coffee becomes the variables that determine the quality of the coffee. The aroma of coffee became one of the appeal factors for consumers. The aroma of the Java Preanger coffee is the aroma of nutty and caramel which is similar to the aroma of nuts and floral, with the level of acidity like lime and sweet combination of roasted tubers, the post-tasting contour feels comfortable and the sensation vibrates afterwards.

Another important factor according to the consumer is the type and quality of roasting with a score of 6.55. This factor determines the character of coffee such as flavor and aroma. So, it has an important role for consumers. The lowest factor of interest according to the consumer is the packaging with a score of 5.82. Consumer perception of coffee packaging is quite low due to the majority of ordinary coffee lovers enjoying coffee at cafes and shops and consumed in the form of a cup of coffee. Next, in Figure 1 will be seen the difference gap of producers and consumers of coffee. 


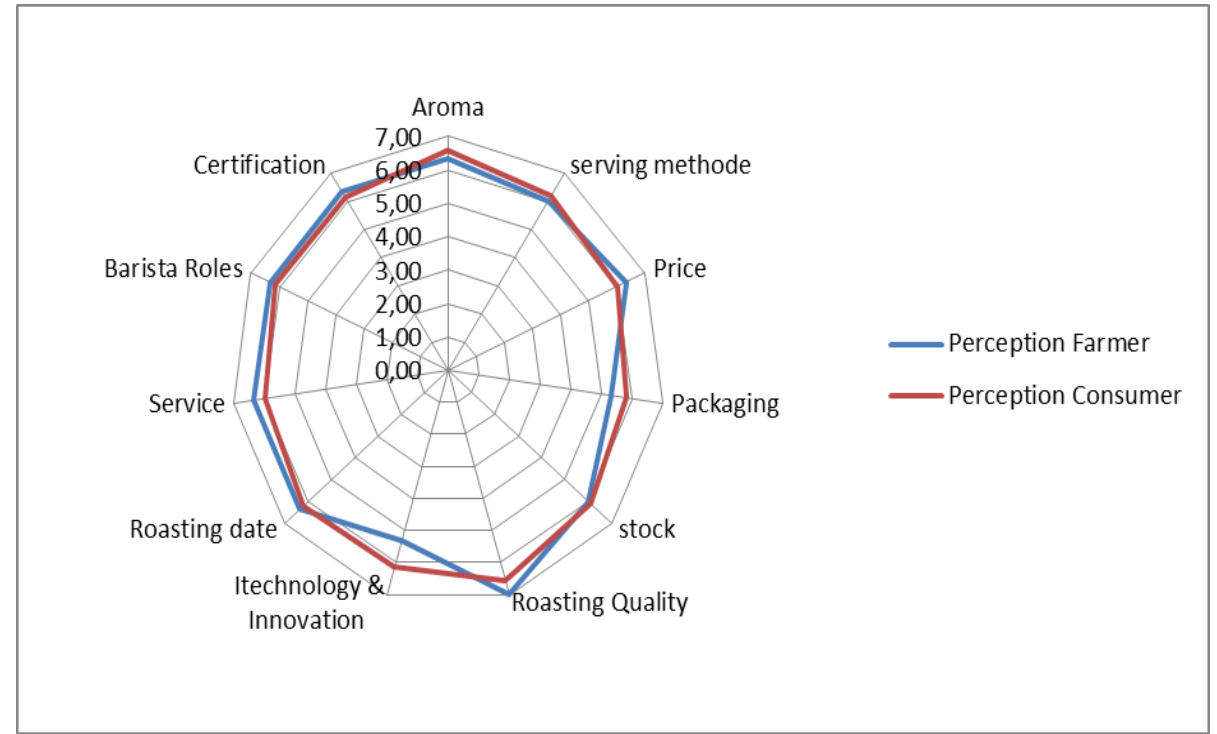

Figure 1. The chart showing the gap between producer and consumer

The factors that become the hope for the consumer have been mostly fulfilled by producers. Although, there are several factors that can not be fulfilled which is shown through the large gap value between farmers and consumers, such as aroma, presentation methods, packaging, innovation and technology and stock or inventory. These five things are an opportunity to upgrade coffee products that will be done by coffee business actors in this case farmers and other entrepreneurs. Aroma becomes a factor that related to the roasting process. Aroma will represent the quality of the roasting and post harvesting method. Aroma, taste and apperance becoming the quality attributes for consumer (Daviron and Ponte, 2005)

The greatest gap conditions exist in innovation and technology. This is because consumers are always looking for new things from the coffee either by type of processing, product or type of coffee. So, the coffee product should be developed and tried to find something new regularly.

The packaging has a score that is relatively low. Consumers expect it to become better package and informative. The product should be safe to eat and also the growing trend that coffee began to be brewed at home or become one of the typical souvenirs from each region.

\section{CONCLUSION AND SUGGESTION}

Based on analysis results, critical factors which affect consumer interest in buying Java Preanger coffee products are aroma, presentation method, price, packaging, stock, roasting quality, innovation and technology, roasting date, service, barista role, certification or standardization.

The most critical factor according to farmers is the type and quality of roasting obtained from the processing with roasting machine. While the most critical factor according to the consumer is the aroma and the type of roasting quality. Comparison the gap of fsctors importance level between farmers and consumers are innovation and technology of 0.80 ; packing of 0.48 . This inward processing downstream has an important role in meeting consumer preferences in terms of good aroma and packaging

Farmers in this case farmer groups and producer cooperatives can pay attention to the critical factors considered by consumers in buying Java Preanger coffee products. So, they can meet what the end market preference is and it can increase the competitive advantage.

The government in this case must support both the regulation and direct assistance, especially related to the increase of added value and competitiveness of West Java coffee products. Assistance of UPH machine (processing unit of Results) and training about marketing and processing of coffee need to be improved. Then, there is a policy of protection and promotion of local coffee Indonesia such as the implementation of import tariffs of processed coffee products from abroad and the implementation of export subsidy for roasting bean coffee Indonesia for farmers to get added value. 


\section{REFERENCES}

Australian Center for International Agricultural Research. 2012. Making Value Chains Work Better For Poor, Australia

Daviron, B. and S. Ponte.2005. The Coffee Paradox. London [etc.]: Zed Books

Direktorat Jenderal Perkebunan (Ditjenbun). 2014. Pedoman Teknis Budidaya Kopi Yang Baik. Ditjenbun. Jakarta. 60 hal.

Gaille, B. 2013. 25 Coffee Shop Industry Statistics and Trends.

http://brandongaille.com/25-coffee-shopindustry-statistics-and-trends/ access date 02 November 2016

Grunert, K. G. 2005. How changes in consumer behaviour and retailing affect competencerequirements for food producers and processors. Economia Agraria y RecursosNaturales 6(11).

Kaplinsky, R., and M. Morris, 2001. A handbook for value chain research. Ottawa, Canada, International Development Research Center.

Paul Krugman \& Anthony J. Venables, 1995. "Globalization and the Inequality of Nations," The Quarterly Journal of Economics, Oxford University Press, vol. 110(4), pages 857-880. 